\title{
Pengelolaan Sampah Terpadu Pulau Kodingareng Lompo Melalui Program Kuliah Kerja Nyata Pembelajaran Dan Pemberdayaan Masyarakat
}

\author{
Muhammad Syahid $^{1^{*}}$, Irwan Ridwan ${ }^{2}$, Arnis Puspitha $\mathrm{R}^{3}$ \\ ${ }^{1}$ Departemen Teknik Mesin Fakultas Teknik Universitas Hasanuddin \\ ${ }^{2}$ Departemen Teknik Lingkungan Fakultas Teknik Universitas Hasanuddin \\ ${ }^{3}$ Program Studi Ilmu Keperawatan Fakultas Keperawatan Universitas Hasanuddin \\ *syahid@unhas.ac.id
}

\begin{abstract}
Abstrak
Pulau kodingareng lompo dengan jumlah penduduk 4170 jiwa belum memiliki sistem pengelolaan sampah yang baik, sehingga sampah masih banyak yang dibuang kelaut. Sampah masih dibiarkan tertimbun dibelakang rumah warga di pinggir pantai, baik sampah organic maupun anorganik. Kesadaran warga akan pentingnya kebersihan dan kesehatan masih rendah, masih ada sebagian warga yang tidak memiliki WC dan membuang air besar dilaut. Padahal Pulau ini memiliki pasir putih yang cantik sehingga berpotensi untuk menjadi destinasi wisata. Tujuan dari Program KKN PPM Dikti yang dilaksanakan pada tanggal 4 juli -4 Agustus 2018 di Pulau Kodingareng Lompo adalah untuk meningkatkan kesadaran warga untuk tidak membuang sampah dilaut, memiliki kesadaran pola hidup sehat dan bersih dan mampu mengelola sampahnya baik sampah organic dan non organic. Program ini terdiri dari tiga garis besar kegiatan yaitu pemilahan dan pengolahan sampah, pembangunan incinerator ramah lingkungan dan penyuluhan hidup bersih dan sehat. Pengolahan sampah secara terpadu meliputi pemilahan dari rumah tangga antara sampah organik dan non organik, pembuatan kompos untuk sampah organic, daur ulang sampah non organik yang masih bisa dimanfaatkan dan pembakaran sampah dengan menggunakan incinerator ramah lingkungan. Solusi Incenerator ramah lingkungan dibutuhkan karena sulitnya membawa sampah yang ada dipulau ke tempat pembuangan akhir sampah kota Makassar. Penyuluhan Hidup sehat dan Bersih diberikan langsung ke setiap rumah tangga dan anak-anak sekolah.. Setelah program berakhir terlihat ada perubahan pola pikir dan perilaku dari warga.
\end{abstract}

Kata Kunci: Manajemen Sampah, Incinerator ramah lingkungan, Pulau Kodingareng

\begin{abstract}
Kodingareng Lompo Island with a population of 4170 people does not have a good waste management system, there are a lot of garbage dumped into the sea. Garbage is left behind the houses on the beach, both organic and inorganic waste. Citizens' has low awareness of sanitation and healthy life. There are some residents who do not have lavatories and defecate at sea. Even though this island has beautiful white sand and has the potential to become a tourist destination. The purpose of the PPM Dikti KKN Program which was held on 4 July-4 August 2018 on Kodingareng Lompo Island was to increase the awareness of citizens maintain the cleanliness of the sea, to have a healthy and clean lifestyle and be able to manage their organic and non-organic waste. This program consists of three outlines of activities namely waste sorting and processing, construction of environmentally friendly incinerators and extension of clean and healthy life. Integrated waste management includes sorting from households between organic and non-organic waste, composting for organic waste, recycling non-organic waste that can still be used and burning waste by using environmentally friendly incinerators. The solution for an environmentally friendly incinerator is needed because of the difficulty to carry garbage in the island to the Makassar city landfill. Counseling Healthy and sanitation is given directly to every household and school.. After the program, there are changes in the mindset and behavior of citizens.
\end{abstract}


Keywords:Waste Management, Enviromental friendly Incinerator, Kodingareng Lompo

\section{PENDAHULUAN}

Pulau Kodingareng Lompo termasuk dalam kelurahan Kodingareng, kecamatan ujung tanah Kota Makassar, dan berjarak $15 \mathrm{~km}$ dari Makassar. Bentuknya relatif memanjang menjorok keluar (spit), pulau ini mempunyai luas $14 \mathrm{Ha}$. ' Jumlah penduduk di pulau ini kurang lebih 4170 jiwa, dengan mata pencarian $90 \%$ sebagai nelayan dan sisanya usaha lainnya.. Konsentrasi penyebaran penduduk merata, dengan jenis bangunan rumah panggung dan rumah batu. ${ }^{2}$

Kesadaran warga pulau kodingareng lompo untuk mengelola sampah dengan baik masih rendah, sampah masih dibuang dilaut, tidak ada tempat pembuangan akhir sampah untuk masyarakat di pulau dan Pola Hidup sehat masyarakat yang masih rendah. Oleh kerena itu dibutuhkan Bank sampah dengan sistem pengelolaan terpadu ( reduce, reuse dan recycle) untuk mengurangi volume sampah, Pengolahan sampah secara terpadu meliputi pemilahan dari rumah tangga antara sampah organic dan non organic dari rumah tangga, Pemisahan sampah ini menjadi awal yang baik bagi masyarakat dalam pengolahan sampah yang semakin maju. ${ }^{3}$ Manfaat pemisahan sampah organik dan anorganik sangat memudahkan proses daur ulang sampah dan mengurangi volume sampah. Sampah-sampah organik akan lebih cepat membusuk jika dikelompokkan sesamanya. sedangkan sampah-sampah anorganik, menjadi lebih bersih dan mendorong masyarakat untuk lebih bersemangat memanfaaatkan sampah unutuk di daur ulang. sampah organic dirumah tangga dapat diubah menjadi kompos dengan metode takakura, Takakura merupakan salah satu metode pengomposan baik skala rumah tangga maupun skala kawasan dengan menggunakan "Keranjang Takakura". "Keranjang Takakura" adalah alat sederhana berbentuk keranjang yang dapat menampung sampah organik rumah tangga seperti sisa nasi, sayuran, dan sampah organik lainnya dan mengubahnya menjadi kompos. ${ }^{4}$

Pembuatan Incenerator sampah ramah lingkungan sebagai solusi tempat akhir pembuangan sampah di pulau. Salah satu metoda alternatif penanganan pengelolaan sampah dengan skala kecil dapat diterapkan di tingkat RT/ RW, Kelurahan dengan pola pembakaran berteknologi (Incinerator Mini). Pada prinsipnya sampah dapat dikelola dengan pembakaran yang ramah lingkungan, Teknologi incinerator ini adalah salah satu alat pemusnah sampah yang dilakukan pembakaran pada suhu tinggi, dan secara terpadu dapat aman bagi lingkungan sehingga pengoperasian nya pun mudah dan aman, karena keluaran emisi yang dihasilkan ramah lingkungan. ${ }^{5}$ Selain itu, dibutuhkan penyuluhan untuk meningkatkan kesadaran warga tentang pengelolaan hidup sehat. Penyuluhan pola hidup bersih sehat, terutama untuk tidak membuang air besar sembarangan dan tidak membuang sampah sembarangan. Demikian juga dengan peningkatan kesadaran untuk mengelola sampah dengan baik.

Program KKN PPM dalam bentuk pengelolaan sampah terpadu dan pemberdayaan kesehatan masyarakat pulau ini diharapkan dapat memberikan manfaat

\footnotetext{
1 "Berwisata ke Pulau Kodingareng Lompo - Gaya Tempo.co", online: 〈https:/gaya.tempo.co/read/335838/berwisata-ke-pulau-kodingareng-lompo〉.

2 "CCDP-IFAD | Profil Desa", online: 〈http://ccdpifad.org/mis2/profildesa.php?\%20target=kecdesa_profil_view\&folder=list\&id=109>.

3 "Diktat Kuliah TL-3104 Pengelolaan Sampah".

${ }^{4}$ Rezagama and Samudro - 2015 - STUDI OPTIMASI TAKAKURA DENGAN PENAMBAHAN SEKAM DA.pdf; Ghufron et al. - 2017 - PELATIHAN PENGOLAHAN SAMPAH ORGANIK MENJADI KOMPOS.pdf.

${ }^{5}$ Firman L Sahwan, "STRATEGI PENGELOLAAN SAMPAH DI KAWASAN KEPULAUAN SERIBU” 5.
} 
bagi peningkatan kualitas hidup masyarakat pulau. Dan juga diharapkan menjadi prototypepengelolaan sampah secara terpadu dan mandiri di pulau-pulau di Indonesia

\section{METODE PELAKSANAAN}

Kegiatan pengabdian ini terdiri atas 3 tahapan yaitu tahapan persiapan pembekalan, Pelaksanaan dan Tahap Evaluasi dan keberlanjutan program. Pada tahap persiapan program ini diintegrasikan dengan program KKN Universitas Hasanuddin dan selanjutnya dilakukan pembekalan (pengetahuan dan keterampilan yang berkaitan). Pada tahap pelaksanaan terdiri dari tiga garis besar program kerja yaitu pengolahan sampah terpadu, pembangunan incinerator ramah lingkungan dan penyuluhan hidup bersih dan sehat. Pengolahan sampah secara terpadu meliputi pemilahan dari rumah tangga antara sampah organik dan non organik, pembuatan kompos untuk sampah organic, daur ulang sampah non organik yang masih bisa dimanfaatkan dan pembakaran sampah dengan menggunakan incinerator ramah lingkungan. Penyuluhan Hidup sehat dan Bersih diberikan langsung ke setiap rumah tangga dan siswa sekolah.. Pelaksanaan Kegiatan dilokasi pada tanggal 4juli -5 Agustus 2018. Pada tahap terakhir dilakukan evaluasi bersama warga.

\section{HASIL DAN PEMBAHASAN}

\section{A. Pengelolaan Sampah Terpadu}

Program kerja yang tergolong dalam kelompok ini adalah Pelatihan sistem pengelolaan sampah terpadu, Pendampingan pemilahan Sampah rumah tangga, Pelatihan Pembuatan Kompos Takakura, dan pelatihan hidroponik menggunakan media bahan bekas. Pelatihan Sistem Pengelolaan Bank Sampah Terpadu Bagi Pengelola Bank Sampah.dilaksanakan pada 9 juli 2018 pukul 16.00-17.00 WITA. Sosialisasi dilaksanakan di Baruga Kelurahan Pulau Kodingareng Lompo. Sosialisasi dihadiri oleh ketua-ketua Rukun Warga (RW) dan Rukun Tetangga (RT), tokoh-tokoh masyarakat, dan masyarakat umum.

Materi yang dibawakan antara lain pengenalan jenis sampah organik dan anorganik, pemilahan sampah yang baik dan benar, manfaat-manfaat jika Bank Sampah diaktifkan kembali di Pulau Kodingareng Lompo, dan mekanisme kerja Bank Sampah. Pemateri juga memberitahukan jenis wadah yang akan digunakan untuk pemilahan sampah, lebih detailnya diberitahukan 3 jenis kantong plastik dengan warna berbeda yaitu merah untuk jenis sampah organik, merah muda untuk jenis sampah anorganik bernilai jual dan hitam untuk jenis sampah anorganik tak bernilai jual. Pemateri berupaya untuk memberikan pemahaman bahwa sampah merupakan bagian yang tidak dapat dipisahkan dari kegiatan sehari-hari masyarakat, bahwa perlu penanganan khusus terkait pengelolaan sampah, perlunya peran serta masyarakat dalam pengaktifan kembali bank sampah oleh pemerintah setempat.

Pelatihan pengelolaan sampah terpadu juga dirangkaikan dengan pelatihan pembuatan kompos Takakura dan pelatiham hidroponik. Metode pelatihan pembuatan kompos takakura yang digunakan yaitu metode tutorial agar warga lebih mudah memahami cara pembuatan kompos Takakura. Kompos takakura merupakan salah satu metode pengolahan sampah organik skala rumah tangga yang diperkenalkan pertama kali oleh ahli kimia terapan dari Jepang yang bernama Koji Takakura. Kelebihan dari metode kompos takakura adalah mudah diaplikasikan dan harganya relative murah 
sehingga sangat cocok diaplikasikan dalam pengolahan sampah organik skala rumah tangga.

Pelatihan hidroponik menggunakan metode learning grup, dimana peserta pelatihan dibagi kedalam dua kloter, sehingga satu kloter terdiri dari 10-15 warga. Metode ini dianggap efektif untuk model pelatihan, karena peserta bisa lebih leluasa bertanya dan pemateri bisa menjelaskan dengan lebih terfokus karena pesertanya dibatasi. Masyarakat memiliki minat yang besar akan teknik bercocok tanam hidroponik ini, terlihat dari antusiasme mereka dalam menerima materi dan keaktifan mereka dalam bertanya.. Selain memberikan materi pelatihan bagaimana bercocok tanam hidroponik, penanggung jawab Program kerja juga membagikan bibit kangkung dan sawi, serta semaian kangkung dan sawi yang telah siap pindah ke wadah plastik hidroponik. penanggung jawab program juga melakukan beberapa kali kunjungan ke rumah-rumah warga untuk melihat bagaimana kelanjutan program ini.

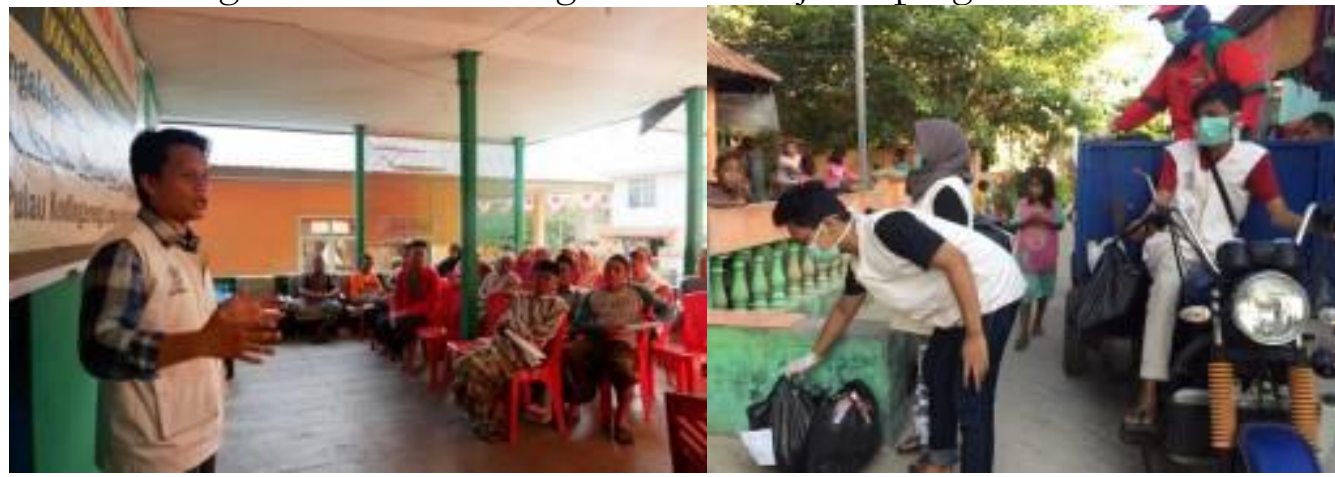

Gambar l. (a) Pelatihan Manajemen Bank Sampah (b) Pendampingan pemilahan sampah rumah tangga

Program kerja Pendampingan Pengelolaan Bank Sampah. dilakukan selama tiga kali dalam seminggu yaitu hari selasa, jumat dan minggu. Proses pendampingan bank sampah ini melibatkan 39 KK (Kepala Keluarga) di RW 2 RT 3 pulau Kodingareng Kecamatan Sangkarrang, Kota Makassar. Tahap pendampingan dimulai dengan dilakukannya pembagian kantong sampah plastik kepada warga dengan tiga jenis warna kantong plastik yang berbeda yaitu kantong plastik berwarna merah sebagai tempat pembuangan sampah organik (sisa makanan), kantong plastik berwarna merah jambu sebagai tempat pembuangan sampah non organik (bisa dijual), dan kantong plastik berwarna hitam sebagai tempat pembuangan sampah non organik (tidak bisa dijual). Kantong plastik yang dibagikan disertakan dengan penjelasan tentang jenis sampah yang akan di pilah dan dimasukkan kedalam kantong plastik sampah agar warga lebih mudah memilah sampahnya dengan benar.

Pada tahap selanjutnya penanggung jawab kegiatan melakukan pengecekkan dan memberi pemahaman kembali masyarakat yang masih salah dalam memilah sampah. Pada jadwal yang telah ditentukan, sampah yg sudah sesuai menurut jenisnya dijemput dan di angkut kemudian di bawa ke bank sampah, incenerator, dan sampah organik itu sendiri di buat kompos gabungan. Pengecekan itu dilakukan selama dua minggu, dan untuk minggu ketiga serta minggu keempat warga diarahkan untuk membawa sampahnya sendiri yang telah mereka pilah ke lokasi Incenerator sampah ramah lingkungan untuk sampah kantong plastik hitam, sampah kantong plastik merah

\footnotetext{
${ }^{6}$ M Ali Ghufron et al, "PELATIHAN PENGOLAHAN SAMPAH ORGANIK MENJADI KOMPOS DENGAN MEDIA KERANJANG TAKAKURA” (2017) l:1 J-ABDIPAMAS J Pengabdi Kpd Masy 98.
} 
jambu dibawa langsung ke Bank Sampah untuk selanjutnya di timbang, dan untuk sampah yang ada di kantong plastik merah langsung dibawa masuk ke tempat pembuatan kompos gabungan

\section{B.Pembangunan Incinerator Sampah Ramah Lingkungan}

Sampah yang merupakan permasalahan utama di Pulau Kodingareng Lompo menjadi fokus dari pembangunan incinerator ramah lingkungan. Incinerator sebagai teknologi pengolahan sampah diharapkan dapat menekan volume/massa sampah di pulau ini. Dengan adanya Incenerator sampah ini, sampah dipulau kodingareng tidak langsung dibuang kelaut terutama sampah plastic, karena dapat merusak ekosistem laut.

Sebagai langkah awal, perancangan incinerator sampah ramah lingkungan menggunakan Autodesk Inventor. Proses perancangan incinerator membutuhkan waktu 1-2 minggu yang kemudian dievaluasi kemudian. Sistem Incenerator ini tidak menggunakan burner, sampah kering dibakar menggunakan pemantik, selanjutnya akan terbakar sendiri oleh sampah tersebut. Asap yang dihasilkan akan dilewatkan pada sistem pencuci asap. Dimana air yang berasal dari tendon disemprotkan pada pipa tempat mengalirnya asap sehingga partikel-partikel asap bisa ditangkap oleh kabut air dan dialirkan kembali ketandon air. Sistem pencuci asap ini menggunakan daya listrik dari tenaga matahari.

Proses selanjutnya yakni pengadaan material untuk membangun incinerator. Bahan berupa panel surya, pompa air, inverter, aki, filter air, pipa besi, dan plat baja dibeli dari kota Makassar karena keterbatasan material di pulau Kodingareng Lompo. Bahan lainnya berupa semen, pasir, batu kerikil, besi beton, paku, dan bahan lainnya yang dapat diperoleh di lokasi KKN dibeli langsung di pulau Kodingareng Lompo. Selanjutnya material dari kota Makassar di mobilisasi menuju Pulau Kodingareng Lompo menggunakan kapal motor. Pembangunan incinerator dimulai pada tanggal 9 Juli 2018, dimulai dengan membersihkan lokasi incinerator yang telah ditetapkan. Kemudian tim melakukan penggalian pondasi, pengecoran pondasi, pemasangan batu merah, plester, dan aci. Campuran yang digunakan memadukan antara semen biasa dan semen tahan api.

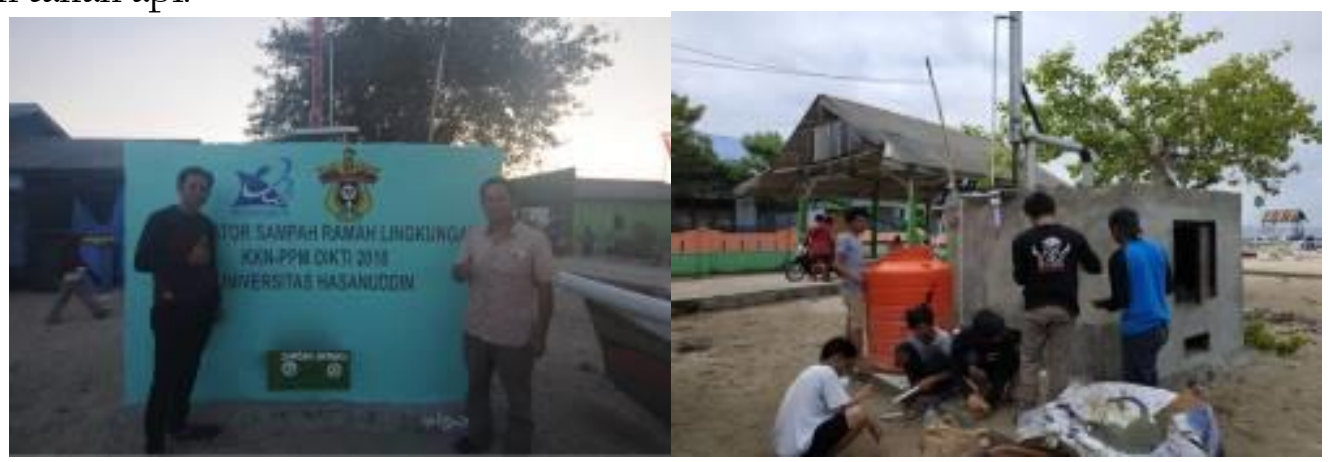

Gambar 3. Pembangunan Incinerator Ramah Lingkungan

Pada tanggal 17 Juli 2018 dilakukan pemasangan instalasi air meliputi pompa air, perpipaan, serta katup. Instalasi air yang dipasang pada incinerator menggunakan filter air dengan tujuan air yang disemprotkan pada incinerator dapat disirkulasikan kembali sehingga air yang digunakan dapat digunakan kembali. Selanjutnya dilakukan pemasangan instalasi kelistrikan meliputi pemasangan panel surya, inverter, aki, dan kabel. Setalah seluruh instalasi selesai dipasang, maka tim melakukan uji coba pertama. 
Uji coba pembakaran sampah pertama dilakukan pada tanggal 24 Juli 2018, setelah itu dilakukan pengecekan semua sistem incinerator meliputi kontrol panel solar cell, pada kontrol panel solar cell dapat melakukan pengisian secara maksimal, kedua sistem pembakaran, pada sistem ini terjadinya pembakaran yang kurang maksimal yang diakibatkan oleh kurangnya oksigen yang masuk dalam ruang pembakaran. Uji coba kedua dilakukan pada tanggal 26 Juli 2018 dengan pembaharuan dari uji coba pertama tim melakukan perubahan cerobong asap pada incinerator dan penambahan blower pada sistem pembakaran.

\section{Peningkatan Kesadaran Pola Hidup Bersih dan Sehat}

Untuk mendukung Pengolahan sampah terpadu dipulau kodingareng juga dilakukan program peningkatan kesadaran pola hidup bersih dan sehat. Proram tersebut meliputi Program PHBS rumah tangga, PHBS di sekolah, Kerja bakti bersama warga dan anak sekolah, Pemeriksaan kesehatan gratis dan pemasangan papan wicara bebas sampah. Perilaku Hidup Bersih dan Sehat (PHBS) adalah semua perilaku kesehatan yang dilakukan atas kesadaran, sehingga anggota keluarga dapat menolong dirinya sendiri di bidang kesehatan.

PHBS di Rumah Tangga adalah upaya untuk memberdayakan anggota rumah tangga agar tahu, mau dan mampu melaksanakan perilaku hidup bersih dan sehat serta berperan aktif dalam gerakan kesehatan di masyarakat. PHBS di Rumah Tangga dilakukan untuk mencapai Rumah Tangga Sehat. Terdapat beberapa indikator dari Perilaku Hidup Bersih dan Sehat di Rumah Tangga, antara lain Persalinan ditolong oleh tenaga Kesehatan, Memberi bayi ASI eksklusif, Menimbang bayi dan balita, Menggunakan air bersih, Mencuci tangan dengan air bersih dan sabun, Menggunakan Jamban Sehat, Memberantas jentik di rumah, Makan buah dan sayur setiap hari, Melakukan aktivitas fisik setiap hari, Tidak merokok di dalam rumah. ${ }^{7}$

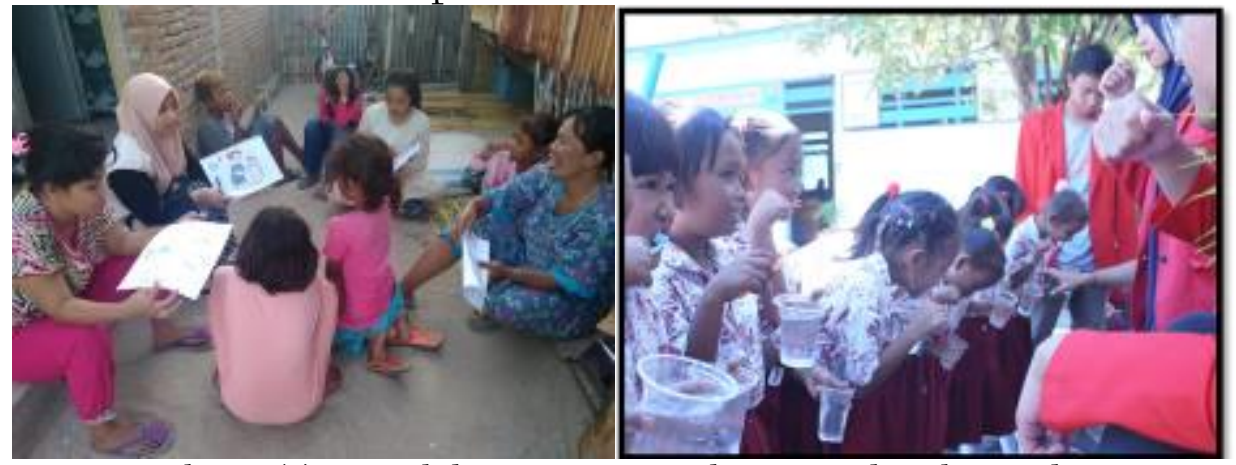

Gambar 4 (a) Penyuluhan PHBS Rumah Tangga di Pulau Kodingareng

(b) Penyuluhan PHBS di sekolah

Sosialisasi PHBS Rumah Tangga dilakukan di RW 02/RT 03 Kelurahan Pulau Kodingareng, Kecamatan Kepulauan Sangkarrang, Kota Makassar. Kegiatan ini berlangsung selama 5 hari berturut-turut yakni terhitung sejak tanggal 10 Juli 2018 hingga 14 Juli 2018. Target sasaran yakni sebanyak 50 rumah tangga dengan metode rumah ke rumah secara random atau acak. Media pendukung sosialisasi yang digunakan adalah flipchart dan leaflet. Program PHBS rumah tangga ini bekerja sama dengan Dinas Kesehatan Kota Makassar dan Puskesmas Pulau Kodingareng yang berfokus pada

\footnotetext{
${ }^{7}$ Ardini S Raksanagara \& Ahyani Raksanagara, "Perilaku Hidup Bersih dan Sehat Sebagai Determinan Kesehatan yang Penting pada Tatanan Rumah Tangga di Kota Bandung” (2015) 15.
} 
pemberantasan jentik di rumah tangga. Tiap rumah yang dikunjungi terdapat sebanyak 2-3 orang yang berlaku sebagai pemateri dan dokumenter. Kegiatan Sosialisasi diakhiri dengan melakukan observasi terhadap tempat penampungan air yang digunakan oleh anggota rumah tangga, pendataan mengenai keberadaan jentik pada tempat penampungan air tersebut, dan pembagian bubuk abate pada setiap rumah yang dikunjungi.

Sosialisasi PHBS Sekolah dilakukan di SD Kodingareng, SMPN 38 Makassar dan SMA Citra Bangsa dengan materi cucitangan pakai sabun, pemilan sampah, gosok gigi. Sedangkan pada smp dan sma dilakukan penyuluhan bahaya rokok dan narkoba. Kegiatan lain yang dilakukan untuk menigkatkan kesadaran warga adalah mengajak warga untuk berpartisipasi aktif pada kegiatan kerja bakti. Kerja bakti ini dilakukan pada spot dermaga dan pantai gusung dengan melibatkan warga dan anak-anak sekolah. Selain itu dipasang papan wicara di tiga titik untuk mengingatkan warga agar tidak membuang sampah ke laut.

\section{Evaluasi Program}

Pada akhir program KKN PPM dilakukan seminar evaluasi program untuk mengukur perubahan mind set setelah program berlangsung. Kegiatan ini juga dimaksudkan agar warga bisa melanjutkan program ini agar bisa berkelanjutan. Berdasarkan wawancara yang dilakukan atau dengar pendapat yang diberikan pada saat seminar, warga memahami pentingnya menjaga kebersihan pulau, berterima kasih kepada mahasiswa yang telah menginisiasi kebersihan pulau ini. Meskipun demikian, mereka khawatir program ini tidak akan berkesinambungan setelah KKN berakhir.

\section{KESIMPULAN}

Kegiatan KKN PPM di Pulau kodingareng meliputi 3 garis besar program yaitu pengelolaan sampah terpadu, pembangunan incinerator ramah lingkungan dan peningkatan kesadaran Pola Hidup Bersih dan Sehat. Warga sangat berterima kasih dengan adanya program ini dan terdapat perubahan pola pikir dan perilaku setelah dilakukannya program ini. Namun perlu ada program selanjutnya agar bisa berkelanjutan

\section{ACKNOWLEDGEMENT}

Kegiatan Pengabdian masyarakat KKN-PPM ini dibiayai dari Hibah Pengabdian Simlitabmas Kemenristek Dikti

\section{DAFTAR PUSTAKA}

Ghufron, M Ali et al. "PELATIHAN PENGOLAHAN SAMPAH ORGANIK MENJADI KOMPOS DENGAN MEDIA KERANJANG TAKAKURA” (2017) l:1 JABDIPAMAS J Pengabdi Kpd Masy 98.

Raksanagara, Ardini S \& Ahyani Raksanagara. "Perilaku Hidup Bersih dan Sehat Sebagai Determinan Kesehatan yang Penting pada Tatanan Rumah Tangga di Kota Bandung" (2015) 15.

Sahwan, Firman L. "STRATEGI PENGELOLAAN SAMPAH DI KAWASAN KEPULAUAN SERIBU" 5.

"Diktat Kuliah TL-3104 Pengelolaan Sampah".

"Berwisata ke Pulau Kodingareng Lompo - Gaya Tempo.co", online: 〈https://gaya.tempo.co/read/335838/berwisata-ke-pulau-kodingareng-lompo〉. 
350 | Pengelolaan Sampah Terpadu Pulau Kodingareng Lompo Melalui Program Kuliah Kerja Nyata Pembelajaran Dan Pemberdayaan Masyarakat

"CCDP-IFAD | Profil Desa", online: 〈http://ccdpifad.org/mis2/profildesa.php?\%20target=kecdesa_profil_view\&\&folder=list\&\&id=109 $>$.

Rezagama and Samudro - 2015 - STUDI OPTIMASI TAKAKURA DENGAN PENAMBAHAN SEKAM DA.pdf.

Ghufron et al. - 2017 - PELATIHAN PENGOLAHAN SAMPAH ORGANIK MENJADI KOMPOS.pdf. 